\title{
Flock dynamics of desert Barki sheep in relation to age structure
}

\author{
A. Y. Abdel - Moneim • A. M. Ahmed • \\ Mona M. Ibrahim • M. M. Mokhtar
}

Accepted: 5 November 2008 / Published online: 25 November 2008

(C) The Author(s) 2008. This article is published with open access at Springerlink.com

\begin{abstract}
Reproduction data of 8689 ewe records spread over 40 years (from 1960 to 2000) representing 2952 breeding Barki ewes were used in this study. The flock belonged to the Desert Research Center in Egypt. Flock dynamics of nine age groups (2-10 yrs) were assessed. Two parameters were used to evaluate flock dynamics, net reproduction rate $\left(\mathrm{R}_{\mathrm{o}}\right)$ (number of ewe- lambs reaching joining age and produced by each ewe during its lifetime in the flock) and intrinsic rate of increase $\left(r_{m}\right)$ (flock growth when no resource is limiting). Age of ewe had a highly significant $(\mathrm{P}<$ 0.01 ) effect on number of ewes lambing per ewe joined $\left(E_{P J}\right)$, number of lambs born per ewe joined $\left(\mathrm{L}_{\mathrm{BJ}}\right)$, number of lambs weaned per ewe joined $\left(\mathrm{L}_{\mathrm{WJ}}\right)$ and number of ewe lambs reaching joining age per ewe joined $\left(\mathrm{L}_{\mathrm{EJ} J \mathrm{~J}}\right)$. All estimates tended to increase with dams age up to four years and decreased thereafter. The results of $R_{o}$ and $r_{m}$ showed that the studied flock must consist of 5 age groups to maintain its size and replace itself. It may be recommended to cull the breeding ewe at the age of 6 years to accelerate genetic improvement.
\end{abstract}

A. Y. Abdel - Moneim ( $\square)$

Department of Animal Production, Faculty of Agriculture, Cairo University,

Giza, Egypt

e-mail: moneim3@yahoo.com

A. M. Ahmed · M. M. Ibrahim • M. M. Mokhtar

Desert Research Center, Animal Production Department,

Matariya, Cairo, Egypt
Keywords Barki sheep · Flock dynamics ·

Intrinsic rate of increase $\left(\mathrm{r}_{\mathrm{m}}\right) \cdot$ Net reproduction rate $\left(\mathrm{R}_{\mathrm{o}}\right)$

\begin{tabular}{|c|c|}
\hline Abbr & iations \\
\hline$d_{x}$ & age specific death rates \\
\hline $\mathrm{E}_{\mathrm{PJ}}$ & number of ewes lambing per ewe joined \\
\hline $\mathrm{L}_{\mathrm{BJ}}$ & number of lambs born per ewe joined \\
\hline $\mathrm{L}_{\mathrm{EJ} . J}$ & $\begin{array}{l}\text { number of ewe lambs reaching joining age } \\
\text { per ewe joined }\end{array}$ \\
\hline $\mathrm{L}_{\mathrm{WJ}}$ & number of lambs weaned per ewe joined \\
\hline$r_{\mathrm{m}}$ & intrinsic rate of increase \\
\hline $\mathrm{R}_{\mathrm{o}}$ & net reproduction rate \\
\hline
\end{tabular}

\section{Introduction}

Population dynamics is the study of factors affecting the growth and decline of a population. Additions to a population can occur through birth, while declines in a population occur through deaths and culling. The birth and death rates of a population depend upon the age of the individuals in the population (El-Shishiny et al. 1987; Pianka 1994 and Oishi et al. 2008). The number of age groups of ewes depends on the reproduction rate. Abegaz et al. (2002) reported that flock management for optimal age structure should receive due consideration to improve lambing rate and litter size in Horro sheep.

Net reproduction rate $\left(\mathrm{R}_{\mathrm{o}}\right)$ and intrinsic rate of increase $\left(r_{m}\right)$ are two major parameters used to 
measure the flock dynamics. $\mathrm{R}_{\mathrm{o}}$ is the number of ewelambs reaching joining age and produced by each ewe during its lifetime in the breeding flock (Turner and Young 1969; Pianka 1994 and Rose 2003). The value of $R_{o}$ can provide information on the replacement rate required for maintaining flock size. If $R_{o}$ is equal to one, the flock will maintain its size. If it is greater than one, the flock is increasing in size and if less than one the flock is decreasing (Pianka 1994). In this context, $r_{m}$ represents the exponential rate of population growth when no resource is limiting. The value of $r_{m}$ is one of the most important characteristics of a flock (Pianka 1994). It can be interpreted as the birth rate minus the death rate. If $r_{m}=0$, the flock is stable, if $r_{m}<0$, flock is declining and if $r_{m}>0$, the flock is growing.

In Egypt, there are almost 5.2 million head of sheep (FAO 2007), out of which one third is maintained in the western desert specially in the north western coastal area. Barki sheep, which is the dominant coarse wool fat- tailed breed of this area, is known to be well adapted to the harsh prevailing conditions including poor feeding, heat stress and diseases.

The objective of this research was to examine the replacement rates, flock structures and dynamics of a Barki sheep flock belonging to Desert Research Center spread over 40 years. Determination of the best culling policy of such flock was also considered.

\section{Materials and methods}

Source of data

Data used in the present study were obtained from a flock of Barki sheep reared in Ras-Elhekama and Maryout research stations of the Desert Research Center during the period from 1960 to 2000. RasElhekma is located in north western coastal desert of Egypt, $218 \mathrm{~km}$ west of Alexandria. In 1972 the flock was transferred to Maryout research station, located some $30 \mathrm{~km}$ south west of Alexandria.

\section{Management practices}

In Ras-Elhekma research station sheep were kept in open partially shaded wire - fenced yards. Ewes management practices were nearly similar in both stations. Ewes remained within their flock unless they missed two consecutive lambings, had any serious unsoundness that impair performance (i.e. lameness, bad udder and prolapse) or death and were replaced with younger ewes. Flushing was done two weeks before mating season. Mating season usually lasted for two or three estrous cycles and started in June or July. Breeding rams were replaced every two years with selected ram lambs. After mating, ewes were separated from rams and were kept as one group until lambing.

Lambing season usually started from November. The effective service date was recorded by matching markings and lambing dates for the ewes in the breeding pens. Just after birth, each lamb was individually identified with an ear tag and was weighed. Lambs suckled their mothers freely and were weighed biweekly up to weaning at about 4 months of age, then weaned lambs joined the flock, and lambs grazed with the rest of the flock.

At the age of 18 months female lambs were selected for heavier weight, soundness, healthy state and body conformation. Culling was performed before mating season, according to the specific criteria, age of breeding ewes, reproductive performance and hygienic conditions.

In both stations, the breeding season began in June, but from 1990 onwards ewes were bred in September.

\section{Feeding}

In Ras-Elhekma station, sheep were allowed to graze the natural range from October to March in neighboring pasture according to range conditions. The pasture growth depends on rain which varies greatly from year to year and even within months of the same season.

During grazing season, liberal amount of wheat straw (Triticum aestivum) as well as $0.25 \mathrm{Kg} / \mathrm{head} /$ day of a concentrate mixture were offered to the animals upon returning from pasture according to the range conditions. The concentrate mixture consisted of $65 \%$ undecorticated cotton seed meal, $12 \%$ wheat bran, $20 \%$ rice polish, $2 \%$ limestone and $1 \%$ common salt.

During late pregnancy (60 days before expected parturition) and along early lactation (60 days after lambing), ewes were supplemented daily with $500 \mathrm{~g}$ of the concentrate mixture. During summer months 
(April to September) natural grazing was not available. Wheat or barely straw as well as berseem (Trifolium alexandrinum) hay, were offered ad. lib. to the flock beside the concentrate mixture. Animals were drenched with vitamin A periodically. In Maryout research station sheep were fed on berseem hay $a d$. lib. Additionally 0.5 to $1.0 \mathrm{~kg}$ of a concentrate mixture was offered daily per head according to their physiological status. The concentrate mixture consisted of $50 \%$ undecorticated cotton seed cake, $18 \%$ wheat bran, $15 \%$ yellow maize, $11 \%$ rice polish, $3 \%$ molasses, $2 \%$ limestone and $1 \%$ common salt. Whenever available, sheep were allowed to graze alfalfa in neighboring areas from sunrise until before sunset. Sheep were allowed to drink water twice daily.

\section{Data}

Information on the breeding, reproductive and feeding aspects of the flock was routinely collected by welltrained technicians. The hand-written records were transferred to the computer in 2003. A total of 8689 reproductive records collected between 1960 and 2000 representing 2952 breeding ewes were analysed in this study.

\section{The reproductive parameters studied were:}

1. Age specific death rates $\left(\mathrm{d}_{\mathrm{x}}\right)$ : they were calculated from one joining to the next and defined as the losses from death and/ or culling during any age interval, expressed as a proportion of the number of ewes present at the beginning of the interval as suggested by Turner and Young (1969) and Mohan et al. (1986).

2. Number of ewes lambing per ewe joined $\left(E_{P J}\right)$.

3. Number of lambs born per ewe joined $\left(\mathrm{L}_{\mathrm{BJ}}\right)$.

4. Number of lambs weaned per ewe joined $\left(\mathrm{L}_{\mathrm{WJ}}\right)$.

5. Ewe lamb mortality from weaning age to age at first joining.

6. Number of ewe lambs reaching joining age (1.5 years) per ewe joined ( $\left.\mathrm{L}_{\text {EJ.J }}\right)$.

The influence of dam age ( 2 to 10 years) on the reproductive parameters was evaluated using the GLM procedure for repeated measures analysis of variance (SAS 1998). This effect was assumed fixed except the random error, which was assumed normally and independently distributed with mean 0 and variance $\sigma^{2}$. The computation of flock dynamics was done according to Turner and Young (1969) and Mohan et al. (1986).

\section{Results}

It was found that age of ewe exerted a highly significant $(\mathrm{P}<0.01)$ influence on all studied parameters $\left(\mathrm{d}_{\mathrm{x}}, \mathrm{E}_{\mathrm{PJ}}, \mathrm{L}_{\mathrm{BJ}}, \mathrm{L}_{\mathrm{WJ}}\right.$ and $\left.\mathrm{L}_{\mathrm{EJ} . \mathrm{J}}\right)$. It is clear (Table 1) that estimates of age specific death rate $\left(d_{x}\right)$ increased with advancing age of dam. The lowest and highest estimate of $d_{x}$ were obtained from two years and ten years old ewes, respectively (Table 1). Probabilities of

Table 1 Probability of survival for Barki ewes entering the breeding flock and age - specific rates of death, ewes lambing, total lambs born and weaned and ewe lambs surviving to joining age

\begin{tabular}{|c|c|c|c|c|c|c|c|c|c|}
\hline \multirow{2}{*}{$\begin{array}{l}\text { Age group of } \\
\text { ewe (years) }\end{array}$} & \multirow{2}{*}{$\begin{array}{l}\text { Average } \\
\text { age (years) } \\
(\bar{x})\end{array}$} & \multirow{2}{*}{$\begin{array}{l}\text { No. of } \\
\text { Records }\end{array}$} & \multirow{2}{*}{$\begin{array}{l}\text { Deaths* } \\
\left(d_{\mathrm{x}}\right)\end{array}$} & \multicolumn{2}{|c|}{ Probability of survival to } & \multirow{2}{*}{$\begin{array}{l}\text { Ewes } \\
\text { lambing * } \\
\left(\mathrm{E}_{\mathrm{PJ}}\right)\end{array}$} & \multirow{2}{*}{$\begin{array}{l}\text { Total } \\
\text { lambs born* } \\
\left(\mathrm{L}_{\mathrm{BJ}}\right)\end{array}$} & \multirow{2}{*}{$\begin{array}{l}\text { Total lambs } \\
\text { weaned* } \\
\left(\mathrm{L}_{\mathrm{WJ}}\right)\end{array}$} & \multirow{2}{*}{$\begin{array}{l}\text { Ewe lambs } \\
\text { reaching } \\
\text { joining age* } \\
\left(\mathrm{L}_{\text {EJ..J }}\right)\end{array}$} \\
\hline & & & & $\begin{array}{l}\text { Beginning of } \\
\text { age group } \\
\left(l_{\mathrm{x}}\right)^{1}\end{array}$ & $\begin{array}{l}\text { Average age } \\
(l \bar{x})^{2}\end{array}$ & & & & \\
\hline $1.5-2.5$ & 2 & 1785 & 0.077 & 1 & 0.962 & 0.802 & 0.818 & 0.649 & 0.269 \\
\hline $2.5-3.5$ & 3 & 1748 & 0.110 & 0.923 & 0.872 & 0.835 & 0.857 & 0.711 & 0.304 \\
\hline $3.5-4.5$ & 4 & 1553 & 0.125 & 0.822 & 0.771 & 0.855 & 0.897 & 0.766 & 0.348 \\
\hline $4.5-5.5$ & 5 & 1238 & 0.135 & 0.719 & 0.671 & 0.797 & 0.834 & 0.727 & 0.284 \\
\hline $5.5-6.5$ & 6 & 863 & 0.122 & 0.622 & 0.584 & 0.780 & 0.808 & 0.700 & 0.271 \\
\hline $6.5-7.5$ & 7 & 619 & 0.196 & 0.546 & 0.492 & 0.796 & 0.839 & 0.688 & 0.241 \\
\hline $7.5-8.5$ & 8 & 400 & 0.228 & 0.439 & 0.389 & 0.725 & 0.744 & 0.578 & 0.207 \\
\hline $8.5-9.5$ & 9 & 244 & 0.327 & 0.339 & 0.284 & 0.771 & 0.840 & 0.593 & 0.214 \\
\hline $9.5-10.5$ & 10 & 239 & 0.369 & 0.228 & 0.186 & 0.725 & 0.782 & 0.479 & 0.127 \\
\hline
\end{tabular}

*All parameters are per ewe joined, ${ }^{1} l_{\mathrm{x}}=l_{\mathrm{x}-1}\left(1-\mathrm{d}_{\mathrm{x}-1}\right),{ }^{2} l_{\bar{x}}=l_{x}\left(1-d_{x} / 2\right)$ 
both survival of the breeding ewes at the beginning of age group $\left(l_{\mathrm{x}}\right)$ and at average age $\left(l_{\bar{x}}\right)$ decreased with increasing number of age groups in the flock (Table 1). Meanwhile, the probability of survival of the breeding ewes entered the breeding flock at the beginning of age group at 1.5 years old up to average age was 0.962 (Table 1). Furthermore, the results in Table 1 showed that the probability of those breeding ewes to be alive to the beginning of the next age group (2.5 years old) was 0.923 and 0.872 at average age ( 3 years old). As the breeding ewes advanced in age, the probability to be alive and stay in the current flock decreased. Consequently, the probability of survival of the breeding ewes aged 2 years old became 0.228 at the beginning of last age group (9.5 years old) and 0.186 at average age (10 years old) of the flock size (Table 1).

On the other hand, all other parameters $\left(\mathrm{E}_{\mathrm{PJ}}, \mathrm{L}_{\mathrm{BJ}}\right.$, $\mathrm{L}_{\mathrm{WJ}}$ and $\mathrm{L}_{\mathrm{EJ.J}}$ ) tended to increase with increasing age of dam up to 4 years old and decreased thereafter (Table 1).

In Table 2, $\sum \mathrm{E}_{\mathrm{PJ}}$ increased for the first three age groups ( 2 to 4 years old) to reach 0.829 then gradually and slightly decreased. Furthermore, $\sum \mathrm{L}_{\mathrm{BJ}}$ increased with number of age groups of flock structure till it reached 0.854 at the third age group (4 years old) then decreased gradually up to 10 years of dam age (Table 2). In this context, results in Table 2 showed that $\sum \mathrm{L}_{\mathrm{WJ}}$ increased with increasing age groups up to the fourth age groups (5 years), then gradually decreased until the tenth age.
It is speculated (Table 2) that with increasing the number of age groups, $\sum \mathrm{L}_{\text {EJ.J }}$ reached a maximum of 0.304 at 4 years old (the third age group) then gradually decreased. The value of $\sum \mathrm{L}_{\mathrm{EJ} . J}$ of the studied flock with 9 age groups was 0.273 , which represents the cumulated performance of additional age groups.

The number of ewe lambs required for replacement decreased with increasing number of age groups. While the total number of ewe lambs required for replacement year after year would be 0.177 , their number produced and reached joining age was 0.273 . Subsequently, the total number of surplus ewe lambs would be 0.096 . It is clear that the total number of surplus ewes increased as the number of age groups increased (Table 2).

It could be noticed (Table 3) that when the flock contains 4 age groups or less, $\mathrm{R}_{\mathrm{o}}$ was less than one. Meanwhile, $R_{o}$ value exceeded unity (1.141) at the 5 th age group of the studied flock. In this context, $r_{m}$ was less than zero when the flock consisted of less than 5 age groups (when no selection from surplus ewe lambs was practiced) which means that the flock decreased in size until it includes 5 age groups, since $r_{m}$ became equal or slightly more than zero (Table 3 ). With use of the multiplying factor a flock of 1000 ewes would increase in five years to 1193 ewes (multiplying factor $=1.036^{5}$ ) if all female offspring entered the breeding flock and were culled after lambing at six years of age, and to 1469 ewes (multiplying factor $=1.080^{5}$ ) if ewes were culled after lambing at ten years of age (Table 3).

Table 2 Values of various aspects of reproduction rate for Barki flock of fixed size with different age structures

\begin{tabular}{|c|c|c|c|c|c|c|c|c|}
\hline $\begin{array}{l}\text { Average } \\
\text { age (years) }\end{array}$ & & & $\begin{array}{l}\text { Ewe } \\
\text { lambing }^{1}\end{array}$ & $\begin{array}{l}\text { Total } \\
\text { lambs } \\
\text { born }^{1}\end{array}$ & $\begin{array}{l}\text { Total } \\
\text { lambs } \\
\text { weaned }^{1}\end{array}$ & $\begin{array}{l}\text { Ewe Lambs } \\
\text { reaching } \\
\text { joining age }{ }^{1}\end{array}$ & $\begin{array}{l}\text { Ewes required } \\
\text { for replacement }\end{array}$ & $\begin{array}{l}\text { Surplus ewes } \\
\text { aged } 1.5 \text { years }{ }^{2} \\
\text { (column } 7 \text { - column } 8 \text { ) }\end{array}$ \\
\hline$(\bar{x})$ & $\sum l_{\mathbf{x}}$ & $\sum l_{\bar{x}}$ & $\frac{\sum\left(l \bar{x} \cdot E_{p j}\right)}{\sum l_{\bar{x}}}$ & $\frac{\sum\left(l \bar{x} \cdot L_{B J}\right)}{\sum l_{\bar{x}}}$ & $\frac{\sum\left(l \bar{x} \cdot L_{W J}\right)}{\sum l_{\bar{x}}}$ & $\frac{\sum\left(l \bar{x} . L_{E J . J}\right)}{\sum l_{\bar{x}}}$ & $\frac{1}{\sum l_{x}}$ & \\
\hline 2 & 1.000 & 0.962 & 0.802 & 0.818 & 0.649 & 0.269 & 1.000 & -0.731 \\
\hline 3 & 1.923 & 1.834 & 0.818 & 0.837 & 0.678 & 0.286 & 0.520 & -0.234 \\
\hline 4 & 2.745 & 2.605 & 0.829 & 0.854 & 0.704 & 0.304 & 0.364 & -0.060 \\
\hline 5 & 3.464 & 3.276 & 0.822 & 0.850 & 0.709 & 0.300 & 0.289 & 0.011 \\
\hline 6 & 4.086 & 3.860 & 0.816 & 0.844 & 0.708 & 0.296 & 0.245 & 0.051 \\
\hline 7 & 4.632 & 4.352 & 0.814 & 0.843 & 0.705 & 0.289 & 0.216 & 0.073 \\
\hline 8 & 5.071 & 4.741 & 0.806 & 0.835 & 0.695 & 0.283 & 0.197 & 0.086 \\
\hline 9 & 5.410 & 5.025 & 0.804 & 0.835 & 0.689 & 0.279 & 0.185 & 0.094 \\
\hline 10 & 5.638 & 5.211 & 0.802 & 0.834 & 0.682 & 0.273 & 0.177 & 0.096 \\
\hline
\end{tabular}

\footnotetext{
${ }^{1}$ Per ewe joined, ${ }^{2}$ As a proportion of total number of ewes in breeding flock.
} 
Table 3 Net reproduction rate $\left(\mathrm{R}_{\mathrm{o}}\right)$ for Barki flock with different age structures and intrinsic rate of increase $\left(r_{\mathrm{m}}\right)$ for the flock when no restriction on intake is imposed

\begin{tabular}{|c|c|c|c|c|c|}
\hline \multirow{2}{*}{$\begin{array}{l}\text { Average } \\
\text { age (years) } \\
(\bar{x})\end{array}$} & & \multirow{2}{*}{$\begin{array}{l}\left(\mathrm{R}_{\mathrm{o}}\right) \\
\sum\left(l_{\bar{x}} \cdot L_{E J . J}\right)\end{array}$} & \multirow{2}{*}{$\begin{array}{l}\text { Length of } \\
\text { generation }\left(\mathrm{L}_{F}\right) \\
\frac{\sum\left(l_{\bar{l}} \cdot L_{E J J J} \cdot \bar{x}\right)}{\sum\left(l_{\bar{x}} \cdot L_{E J, J}\right)}\end{array}$} & \multirow{2}{*}{$\begin{array}{l}\left(\mathrm{r}_{\mathrm{m}}\right) \\
\frac{\log _{e} R_{o}}{L_{F}}\end{array}$} & \multirow{2}{*}{$\begin{array}{l}\text { Multiplying factor } \\
\text { antilog }_{e}\left(r_{m}\right)\end{array}$} \\
\hline & $\sum l_{\bar{x}}$ & & & & \\
\hline 2 & 0.962 & 0.259 & 2 & -0.675 & 0.509 \\
\hline 3 & 1.834 & 0.524 & 2.506 & -0.258 & 0.773 \\
\hline 4 & 2.605 & 0.792 & 3.012 & -0.077 & 0.926 \\
\hline 5 & 3.276 & 0.983 & 3.397 & -0.005 & 0.995 \\
\hline 6 & 3.860 & 1.141 & 3.759 & +0.035 & 1.036 \\
\hline 7 & 4.352 & 1.260 & 4.063 & +0.057 & 1.059 \\
\hline 8 & 4.741 & 1.341 & 4.301 & +0.068 & 1.070 \\
\hline 9 & 5.025 & 1.402 & 4.504 & +0.075 & 1.078 \\
\hline 10 & 5.211 & 1.426 & 4.596 & +0.077 & 1.080 \\
\hline
\end{tabular}

\section{Discussion}

There is a strong relationship between reproductive traits and age structure (El-Shishiny et al. 1987; Abegaz et al. 2002; Abbott and Maxwell 2004; Kamalzadeh 2005 and Oishi et al. 2008). Since both age and breeding status influence production, consideration has to be given to determine the flock age structure that gives maximal return. The optimal age structure of a breeding flock is that which gives the greatest economic return (Kobayashi et al. 2003).

In our study, it was found that the probability of breeding ewes to survive and retain in the Barki flock decreased continually through age classes. The decline in survivability with age could be attributed to less viability, decreased productive and reproductive performance and the increase in percentages of culled ewes and mortality rates. The obtained results are in accordance with those of Turner and Young (1969), Mohan et al. (1986), El-Shishiny et al. (1987) and Pianka (1994).

It is apparent from Table 2 that the values of $\sum E_{P J}$ and $\sum \mathrm{L}_{\mathrm{BJ}}$ and $\sum \mathrm{L}_{\mathrm{EJ} . J}$ reached the peak at the 4 th average age. The highest $\sum \mathrm{L}_{\mathrm{WJ}}$ value was attained at the 5th average age. A gradual decline in values of each of these parameters was observed thereafter. Similar results were found by Mohan et al. (1986) on Merino, Nilagiri and halfbred ewes who indicated that the ewes aged 4 years bore more multiple births whereas 5-year- ewes were better mothers weaning more lambs. Meanwhile, El-Shishiny et al. (1987) found that total kilograms weaned for a Rahmany sheep flock increased with increase in the age of ewe, to reach a maximum at the age of 6 years, and declined gradually thereafter.

On the other side, the annual replacement rate is based on ewe lambing and the number of old ewes leaving the flock due to their death and culling during a particular year, decided the intensity of selection as well as maintenance of flock size (Rawal and Tomar 1998). In the present study, it was observed that the number of ewe lambs required for replacement decreased with increase in the number of age groups. Meanwhile, the annual replacement rate of the flock under study was $17.7 \%$. This rate might be taken into account in the culling policy if we cast the breeding ewes at 10 years old or more. This means that the breeding ewe would stay longer in the flock subsequently affects the genetic gain. Hence, it is appropriate to cull the ewe when they are 6 years old in order to improve genetic gain, which corresponds to a replacement of $24.5 \%$. In a commercial flock, applying this replacement rate might be expected to have a good economic return. Similar trend was reported by El-shishiny et al. (1987) who indicated that in commercial flocks, increasing the number of ewes in the most productive age group, usually between 4 and 6 years, is a desired objective. In the meantime, Turner and Young (1969) reported that the overall mean of annual replacement was $12.4 \%$ of a flock of Peppin Merino with 9 age groups of ewes. While, Mohan et al. (1986) reported that the overall mean of replacement rate was 17.8, 18.2 and $16.7 \%$ for Merino, Nilagiri and halfbred ewes, respectively. 
$R_{\mathrm{o}}$ is one of the most important indicators affecting flock dynamics. The value of $\mathrm{R}_{\mathrm{o}}$ provides information about the replacement rate required for maintaining flock size. The attained results of $R_{o}$ showed clearly that the studied flock must consist of at least 5 age groups to maintain its size and replace itself. When $R_{o}$ was around unity (1.141) with 5 age groups, it would be expected that the breeding ewes could have been bred 5 times to replace itself. This result is in accordance with that reported by Tomar and Mahajan (1980) who showed that of every 5 ewe lambs born, only 1 ewe lamb reached the age of the first lambing. Whereas, Taneja (1966) reported that an ewe needs to be mated 4 times before she even bears the lambs, which will replace her. Furthermore, Turner and Young (1969) concluded that the value of net reproduction rate of Peppin Merino ewes reached unity at 4 age groups and decided that the flock would not be viable unless it has 4 age groups. Meanwhile, Mohan et al. (1986) declared that the value of net reproduction rate reached unity at 5 age groups in case of Merino, at 3 age groups in case of Nilagiri and at 4 age groups for halfbred.

Obviously, the results showed that the longer the breeding ewe is retained in the breeding flock, the more ewe lambs she can produce to replace itself. Nevertheless, it is not recommended to keep the breeding ewe for longer time as it will impact the generation interval and subsequently affects negatively the genetic improvement.

On the other side, $r_{m}$ is an important parameter used to determine flock dynamics. It was observed that $r_{m}$ value was negative up to 4 age groups and became greater than zero with 5 age groups and more. Hence, it could be deduced that the current management practices that tended to keep the breeding ewes up to 10 years of age lead to production of more than required lambs for replacement, longer generation interval (4.6 years vs. 3.8 years) and consequently delayed the genetic improvement.

It is clear from the aforementioned discussion that ewe lambs are the main concern and a limiting factor for the replacement rate. The number of replacement ewe lambs became available each year in a flock seems to be one of the most important vital aspects. Thus, to maintain the flock size, annual replacement rate must equalize disposal rates (culling and mortality). Variations in obtained disposal rates give more chance to choose the most appropriate culling policy and culling age with optimum age structure. The attained results showed that as the values of survival rate increased (lower number of disposal breeding ewes), the number of ewe lambs required for replacement decreased.

On the other hand, the pattern of $R_{o}$ showed that every breeding ewe have to be bred 5 times to produce one ewe lamb to replace itself. Furthermore, the obtained results revealed that there is a negative relationship between values of $R_{o}$ and replacement rates. As the values of $R_{o}$ increased the replacement rate decreased. Moreover, comparing the summation of probability of survival and retain of the breeding ewes in the flock with the replacement rate showed that as the death rate increases the annual replacement rate increased, too.

\section{Conclusion}

Keeping the breeding Barki ewe in the flock up to 10 years of age has a negative impact on replacement rate (low), generation interval (longer) and subsequently delays genetic progress. It may be recommended to cull the breeding ewe at the age of 6 years. This culling policy will improve all the reproductive performance of the flock $\left(\mathrm{E}_{\mathrm{PJ}}, \mathrm{L}_{\mathrm{BJ}}\right.$ and $\left.\mathrm{L}_{\mathrm{WJ}}\right)$. Additionally, applying this policy would have a positive impact on the total proportion of ewe lambs reaching joining age per total proportion of lambs born $(35.1 \%$ vs. $32.7 \%)$.

Moreover, this policy will decrease the generation interval from the current one of 4.6 years to 3.8 years and shorten the time needed for genetic progress by 8 months.

Open Access This article is distributed under the terms of the Creative Commons Attribution Noncommercial License which permits any noncommercial use, distribution, and reproduction in any medium, provided the original author(s) and source are credited.

\section{References}

Abbott, K.A. and Maxwell, W.M.C., 2004. Sheep Health and Production. A course for Veterinary Science, Faculty of Veterinary Science, University of Sydney 
Abegaz, S., Duguma, G., Negussie, E., Gelmesa, U., Terefe, F. and Rege, J. E. O., 2002. Factors affecting reproductive performance and estimates of genetic parameters of litter size in Horro sheep. Journal of Agricultural Science, 139, 79-85. doi:10.1017/S0021859602002265

El-Shishiny, H., Mansour, H. and Galal, E. S. E., 1987. Modelling the dynamics of sheep flocks in Egypt. Agricultural Systems, 23, 301-309. doi:10.1016/0308521X(87)90050-3

FAO, 2007. FAO Statistical Yearbook. http://faostat.fao.org/

Kamalzadeh, A., 2005. Modeling the productivity of a breeding sheep flock for different production systems. Asian Australasian Journal of Animal Sciences, 18, 606-612

Kobayashi, M., Howitt, R. E., Jarvis, L. S. and Laca E. A., 2003. Modeling extensive livestock production systems: An application to sheep production in Kazakhstan. Paper presented at the American Agricultural Economics Association. Annual Meeting, Montreal, Canada, July 27-30, 28pp.

Mohan, M., Ulaganathan, V., Rodricks, I. M., Bhuvanakumar, C.K. and Iyue, M., 1986. Reproduction rate and viability of Merino, Nilagiri and halfbred Merino. II. Age specific replacement rate and net reproduction rate. Tropical Animal Health and Production, 18, 177-183. doi:10.1007/BF02359531
Oishi, K., Kahi, A. K., Nagura, Y., Fujita, M. and Hirooka, H., 2008. Effect of culling age of does on milk and meat production in Japanese-Saanen goats. Livestock Science, 114, 220-232. doi:10.1016/j.livsci.2007.05.003

Pianka, E.R., 1994. Evolutionary ecology. 5th edition. Harper Collins College Publishers, New York, 486 pp.

Rawal, S. C. and Tomar, S.S., 1998. Population analysis for loss of cows and replacement index in Tharparkar cattle. Indian Journal of Animal Sciences, 68, 183-184

Rose, M., 2003. Sheep breeding - Net reproduction rate. http:// www.dpi.qld. gov.au/ sheep/ 5012.html

SAS, 1998. Statistical Analysis System. SAS Users Guide: Statistics. SAS Institute Inc. Editors, Cary, NC

Taneja, G.C., 1966. Fertility in sheep. 1.Conception rate in relation to lamb survival. Indian Veterinary Journal, 43, 727-734

Tomar, S. S. and Mahajan, J. M., 1980. Lifetime reproductive performance of Rambouillet ewes under subtemperate conditions. Indian Journal of Animal Sciences, 50, 838843

Turner, H.N. and Young, S.S.Y., 1969. Quantitative genetics in sheep breeding. Macmillan Company of Australia Pvt. Ltd. pp. 229-249 